\title{
Enhanced expression of type 1 procollagen and transforming growth factor- $\beta$ in tuberculin induced delayed type hypersensitivity
}

\author{
A Wangoo, H T Cook, G M Taylor, R J Shaw
}

\begin{abstract}
Aims-Tissue fibrosis is a common and serious consequence of chronic inflammation. The mechanism linking these two processes is poorly understood. The present study has utilised a human in vivo model of a delayed type hypersensitivity (DTH) reaction, the tuberculin Heaf reaction, induced by intradermal tuberculin in BCG immunised subjects, to dissect the relation between these two processes. Methods-Punch skin biopsy specimens were obtained on day 5 , day 13 and six to 16 weeks following the tuberculin Heaf test in 18 subjects with grade 3 or 4 responses. Skin biopsy specimens from six subjects served as controls. The specimens were examined using immunohistochemical staining for type 1 procollagen and transforming growth factor- $\beta$ (TGF- $\beta$ ), as well as in situ hybridisation for type 1 procollagen messenger RNA (mRNA).

Results-Immunohistochemical analysis revealed increased deposition of TGF- $\beta$ in tissue matrix in the biopsy specimens obtained on day 5 following the tuberculin Heaf test. There was also extensive type 1 procollagen staining in the biopsy specimens obtained as early as day 5. Procollagen-1 staining was maximal on day 13 , and was present in biopsy specimens from tuberculin Heaf test sites up to eight weeks after the tuberculin inoculation. The type 1 procollagen was localised within cells surrounding areas of inflammatory infiltrate and in perivascular tissues. The presence of new collagen formation was confirmed by in situ hybridisation using oligonucleotide probes for type 1 procollagen mRNA in cells in sections from biopsy specimens obtained on day 13 .

Conclusions-These data from a human in vivo model of a DTH response indicate that the immune response is intimately associated with an increase in the production of growth factors and the initiation of a fibrotic response.

(f Clin Pathol 1995;48:339-345)
\end{abstract}

Keywords: Delayed type hypersensitivity, fibrosis, type 1 procollagen, TGF- $\beta$.

The persistence of chronic inflammation is commonly associated with progression to tissue fibrosis and permanent organ damage. This is a special problem in the lungs, where it may occur in many interstitial lung diseases, sarcoidosis and untreated tuberculosis. Bronchoalveolar lavage and biopsy studies in these diseases have documented an increase in inflammatory cells, ${ }^{1}$ increases in messenger RNA (mRNA) and protein of growth factors such as platelet derived growth factor- $\beta$ (PDGF(B)) and transforming growth factor- $\beta$ (TGF- $\beta)^{2-6}$ as well as evidence of new collagen formation. ${ }^{6}$ However, it is not clear how the immune and inflammatory reactions are linked to the production of growth factors and the development of fibrosis.

Pulmonary tuberculosis serves as a human disease model of chronic inflammation progressing to lung fibrosis, in which the pathogen and much of the immunology are known. In tuberculosis, purified protein derivative (PPD) specific $T$ cell clones produce interleukin-2 (IL-2) and interferon- $\gamma($ IFN- $\gamma){ }^{7}$ In patients with pulmonary tuberculosis we and others have shown that IFN- $\gamma$ mRNA is present in CD $4+$ cells, ${ }^{89}$ and INF- $\gamma$ mRNA has been found in skin biopsy specimens of patients with positive tuberculin Heaf tests. ${ }^{10}$ IFN- $\gamma$ is known to increase the abundance of the potent fibroblast mitogen PDGF(B) mRNA in alveolar macrophages, ${ }^{4}$ and we have recently shown that IFN- $\gamma$ derived in vitro from PPD stimulated lymphocytes also increases PDGF(B) mRNA in alveolar macrophages. ${ }^{11}$

A positive Heaf test is a classic delayed type hypersensitivity (DTH) response in which intradermal inoculation of tuberculin to an immunised subject results in an influx of mononuclear cells with a visible erythematous or blistered area maximal at five to seven days. In this study we have used this human in vivo model of the tuberculin Heaf test to determine whether there is any increase in profibrotic growth factor production or new collagen production, as this would provide in vivo evidence in humans that the DTH response of tuberculosis progresses to fibrosis.

There are many indices of a fibrotic reaction. The growth factor TGF- $\beta$ is a product of many cells including macrophages and has potent actions in stimulating collagen production by fibroblasts and promoting wound healing. ${ }^{512}$ In this study TGF- $\beta$ was identified in biopsy specimens by immunostaining. The conventional marker for increased fibrosis is an increase in collagen. Newly synthesised collagen can be identified by immunostaining using antibodies directed against the $\mathrm{N}$ or $\mathrm{C}$ terminal peptides of procollagen as these peptides are cleaved and degraded when 
procollagen is converted to mature tissue collagen. ${ }^{1314}$ Similarly, in situ hybridisation for the mRNA of type 1 procollagen can be used to identify cells actively synthesising collagen. ${ }^{15}$

\section{Methods}

Subjects were recruited who had a grade 3 or 4 Heaf test. Twenty four Bacille Calmette Guerin (BCG) immunised volunteers were included. Heaf test (tuberculin PPD, 100000 U/ $\mathrm{ml}$; Evans Medical Ltd., Horsham, Sussex, UK) was administered to 18 volunteers in the forearm and six subjects served as controls. The Heaf test was graded on days 5-7 and punch skin biopsy specimens ( $3 \mathrm{~mm}$ thick) were obtained under local anaesthesia on normal skin from controls and on day 5, day 13 and days 42-120 from volunteers following the tuberculin Heaf test. The biopsy specimens were fixed in $10 \%$ phosphate buffered formal saline and were embedded in paraffin wax. All subjects gave their informed consent and this study was approved by the Parkside Area Health Authority ethics committee.

\section{IMMUNOHISTOCHEMISTRY}

Sections 3-4 $\mu \mathrm{m}$ thick were cut from each biopsy specimen, dewaxed and treated with $3 \%$ hydrogen peroxide in methanol to quench endogenous peroxidase activity. The sections were washed in phosphate buffered saline (PBS; $\mathrm{pH} 7 \cdot 2)$ and were trypsinised $(0.5 \%$ trypsin and $0.5 \%$ chymotrypsin; Sigma) for 10 minutes for type 1 procollagen and 20 minutes for TGF- $\beta$.

Non-specific protein binding was blocked with 1 in 5 dilution of normal porcine serum (Dako, High Wycombe, UK) in PBS. Primary antibodies used in this study were human type 1 procollagen (Gift from Dr M J Warburton, ${ }^{16}$ St Georges Hospital Medical School, London and Chemicon International, Temicula, California, USA) and TGF- $\beta$ (pan specific) (British Biotechnology Products Ltd, Oxon, UK). In initial experiments both antibodies to type 1 procollagen were compared in adjacent slides and gave identical results. The antibodies were diluted in 1 in 20 porcine serum in PBS. The sections were incubated with the optimal dilution of the primary antibodies ( 1 in 400 for procollagen- 1 and 1 in 100 for TGF- $\beta$ in PBS) for one hour in a humidifying chamber at room temperature. The sections were washed with PBS and incubated with biotinylated goat antirabbit (Dako) for 30 minutes, washed and then incubated with avidin-biotin peroxidase complex (Dako), washed for 15 minutes, and visualised with 3,3'-diaminobenzidine (DAB) substrate (Dako). The sections were counterstained with Mayer's haematoxylin solution (Sigma, St Louis, Missouri, USA) for one minute. After colour development, slides were scored for intensity in a coded fashion on a semiquantitative scale from negative $(-)$, weak staining $(+/-)$, definite staining $(+)$, prominent staining $(++)$, and very definite staining $(+++)$. Thus, sections were coded and examined without knowledge of clinical in- formation. Perivascular and other cellular staining were assessed separately. In control sections specificity was ascertained when the primary antibody step was omitted or sections were treated with purified normal rabbit serum (Dako).

\section{IN SITU HYBRIDISATION}

The procedure for in situ hybridisation was modified from the methods described earlier. ${ }^{17}$ Briefly, 3-4 $\mu \mathrm{m}$ sections were cut from tuberculin Heaf biopsy specimens embedded in paraffin wax and were mounted on Vector bond (Vector Laboratories, Burlingame, California, USA) coated slides and baked overnight at $56^{\circ} \mathrm{C}$. Tissue sections were dewaxed and rehydrated through an alcohol series to PBS. Sections were treated with proteinase $K$ (Boehringer Mannheim, UK) $50 \mu \mathrm{m} / \mathrm{ml}$ for $7 \cdot 5$ minutes, washed in PBS followed by acetylation with $0.1 \%$ acetic anhydride in $0.1 \mathrm{M}$ triethanolamine to reduce non-specific interaction between DNA probes and tissue. Slides were washed in PBS, dehydrated and air-dried, and used for hybridisation on the same day or stored at $-20^{\circ} \mathrm{C}$.

For type 1 procollagen, two 27 base synthetic DNA oligonucleotide antisense sequences were made to order (British Biotechnology, UK) to be used as probes. The sequences were 5'ACC AGT CTC ACC ACG ATC ACC ACT CTT-3' (-366 to -392) and 5'-TCC CTT AGC ACC AGT GTC TCC TTT GCT-3' (-2229 to -2255) and were deduced from the published DNA sequence of the human pro a (1) chain of human type 1 procollagen. ${ }^{18} \mathrm{~A}$ cocktail of both oligonucleotides was $3^{\prime}$-end labelled with deoxyadenosine $5^{\prime}-\left(a^{35} S\right)$ thiotriphos (Amersham International, Buckinghamshire, UK). The reaction consisted of $10 \mathrm{pM}$ of each oligonucleotides, $8 \mu \mathrm{l} 5 \times$ buffer (Promega Corporation, Madison, Wisconsin, USA), $4 \mu \mathrm{l}$ terminal deoxynucleotidyl transferase enzyme (Amersham UK), $5 \mu \mathrm{l}{ }^{35} \mathrm{~S}$ (dATP) and $18 \mu \mathrm{l}$ deionised water to make total of $40 \mu \mathrm{l}$. The reaction was incubated at $37^{\circ} \mathrm{C}$ for one hour and 3 '-end labelled probes were purified using Nensorb 20 nucleic acid purification cartridge (NEN Du Pont (UK) Ltd, Stevenage, UK) according to the manufacturer's recommendations.

Tissue sections were overlaid with $100 \mu \mathrm{l}$ hybridisation buffer which consisted of a $50 \%$ solution of formamide (Sigma), $1 \times$ Denhardt's solution, $1 \mathrm{mM} / 1 \mathrm{EDTA}, 100 \mu \mathrm{g} / \mathrm{ml}$ denatured herring sperm DNA, $250 \mu \mathrm{g} / \mathrm{ml}$ yeast tRNA, $10 \mathrm{mM}$ phosphate buffer, $10 \%$ dextran sulphate, and $4 \times$ sodium chloride/sodium citrate (SSC). Before use, hybridisation buffer was heated to boiling for five minutes and quenched on ice and $250 \mu \mathrm{g} / \mathrm{ml}$ polyadenylic acid and $10 \mathrm{mM} / 1$ dithiothreitol was added. The ${ }^{35} \mathrm{~S}$ labelled oligonucleotide probes were diluted in hybridisation buffer to give between 20-30 $\times 10^{6}$ counts per ml. Hybridisation was performed overnight at room temperature. After incubation, the sections were washed with several changes of $1 \times \mathrm{SSC}$ at $54^{\circ} \mathrm{C}$ for one hour. After washing, slides were air-dried and dipped 
in Ilford $\mathrm{K} 5$ nuclear track emulsion (Ilford Ltd, Mobberley, Cheshire, UK). After exposure periods lasting two weeks, the sections were developed in Phenisol developer (Ilford Ltd), fixed in $0.3 \mathrm{~mol} / \mathrm{l}$ sodium thiosulphate $\mathrm{BDH}$ Ltd, Poole, Dorset, UK) washed in deionised water, counterstained in Mayer's haematoxylin (Sigma) and mounted.

For controls, some tissue sections were treated before hybridisation with $20 \mu \mathrm{g} / \mathrm{ml}$ ribonuclease A (Sigma, Poole, Dorset, UK) and 80 units $/ \mathrm{ml}$ ribonuclease $\mathrm{T} 1$ in $\mathrm{PBS}$ at $37^{\circ} \mathrm{C}$ for 30 minutes. Other control slides were included to validate the specificity of the method. These included competition of the radiolabelled oligonucleotides with either the unlabelled probes used at a 50-fold excess ( $350 \mathrm{ng} /$ slide) or with a large excess $(10 \mathrm{mg}=1 \mathrm{nmol} /$ slide) of an unlabelled "irrelevant" oligonucleotide of similar $\mathrm{G}+\mathrm{C}$ composition $(47 \%)$. To verify hybridisation specificity further, slides from one case were probed with the irrelevant 30-mer which had been $3^{\prime}$ tailed with ${ }^{35} \mathrm{~S}$ dATP.

\section{Results}

CHARACTERISTICS OF THE DTH REACTION IN VOLUNTEERS

All the volunteers receiving the tuberculin Heaf test reacted with red induration and swelling at the site of injection and had a Heaf grade of 3 to 4 on days 5-7 (table). The tuberculin Heaf reaction was biopsied at day 5 and day 13 in seven volunteers each and between a period of 42 and 120 days in four volunteers. Biopsy specimens from normal skin of six volunteers served as controls as, in this study, ethical constraints prevented us obtaining additional biopsy specimens of uninvolved skin from subjects with a positive test. Sections stained with haematoxylin and eosin showed the anticipated patchy perivascular and periadnexal infiltration of mononuclear cells on day 5 and day 13 after the tuberculin Heaf test and these biopsy specimens from days 5 and 13 could not be distinguished from one another by either the density of cells infiltrating a given area or by overall percentage of the dermis infiltrated. However, in biopsy specimens taken 42-120 days after tuberculin Heaf injection very few infiltrating cells were observed.

Distribution of TGF- $\beta$ IN tUBERCULIN HEAF BIOPSY SPECIMENS

Immunohistochemical analysis of skin from normal volunteers showed variable but modest staining in the tissue matrix (grades $+/++$ ) but no cellular staining was observed (table, fig 1A). On day 5 following the tuberculin Heaf test, there was increase in TGF- $\beta$ staining in the tissue matrix of grades $++/+++$ (fig 1B). In some sections more prominent cellular staining was observed. In biopsy specimens taken 13 days following the tuberculin Heaf test, TGF- $\beta$ staining was moderate, grades +1 ++ (fig 1C). Similar staining was observed in sections obtained from volunteers at 42-120 days after the tuberculin Heaf test (table). Sections from biopsy specimens from normal skin and tuberculin Heaf reactions (fig 1D) incubated with non-immune antibodies did not reveal any specific staining.

\section{DISTRIBUTION OF TYPE 1 PROCOLLAGEN IN} TUBERCULIN HEAF BIOPSY SPECIMENS

Figure 2 shows type 1 procollagen staining in control skin and in biopsy specimens from tuberculin Heaf reactions. When normal skin was incubated with antibody to type 1 procollagen, minimal focal deposition of type 1 procollagen was observed at perivascular sites and few biopsy specimens showed staining of cells not associated with vessels (table, fig $2 \mathrm{~A}$ ). There was extensive type 1 procollagen staining in those biopsy specimens obtained on

Procollagen-1 and TGF- $\beta$ immunostaining (grade) in tuberculin Heaf biopsy specimens in BCG immunised volunteers on different days after challenge and in normal skin biopsy specimens

\begin{tabular}{|c|c|c|c|c|c|c|}
\hline \multirow[b]{2}{*}{ Section No. } & \multirow{2}{*}{$\begin{array}{l}\text { Interval after Heaf } \\
\text { test (days) }\end{array}$} & \multirow{2}{*}{$\begin{array}{l}\text { Heaf } \\
\text { test grade }\end{array}$} & \multicolumn{2}{|c|}{ Procollagen-1 staining } & \multicolumn{2}{|c|}{$T G F-\beta$ staining } \\
\hline & & & Perivascular & Cellular & Matrix & Cellular \\
\hline \multicolumn{7}{|c|}{$\begin{array}{l}\text { Tuberculin Heaf } \\
\text { biopsy specimens }\end{array}$} \\
\hline 1 & 5 & 4 & $+t$ & + & $+t+$ & - \\
\hline 2 & 5 & $3 / 4$ & +++ & ++ & $++t$ & - \\
\hline 3 & 5 & $3 / 4$ & +++ & ++ & $++t$ & $+1-$ \\
\hline 4 & 5 & 4 & +++ & $+1-$ & $++t$ & - \\
\hline 5 & 5 & 4 & +++ & + & ++ & - \\
\hline 6 & 5 & 4 & ++ & ++ & ++ & $+1-$ \\
\hline 7 & 5 & 4 & + & ++ & +++ & + \\
\hline 8 & 13 & 3 & ++ & ++ & ++ & - \\
\hline 9 & 13 & 4 & ++ & ++ & ++ & - \\
\hline 10 & 13 & 4 & ++ & +++ & + & - \\
\hline 11 & 13 & 4 & $++t$ & +++ & + & - \\
\hline 12 & 13 & 3 & +++ & + & + & - \\
\hline 13 & 13 & 4 & ++ & ++ & $+1-$ & - \\
\hline 14 & 13 & 4 & +++ & ++ & ++ & - \\
\hline 15 & 42 & 4 & ++ & ++ & ++ & - \\
\hline 16 & 90 & 4 & ++ & ++ & + & - \\
\hline 17 & 120 & 4 & + & ++ & ++ & - \\
\hline \multirow{2}{*}{\multicolumn{7}{|c|}{$\begin{array}{l}\text { Normal skin } \\
\text { biopsy specimens }\end{array}$}} \\
\hline & & & & & & \\
\hline 1 & - & - & ++ & + & + & - \\
\hline 2 & - & - & + & + & + & - \\
\hline 3 & - & - & ++ & - & + & - \\
\hline 4 & - & - & $+1-$ & - & $+t$ & - \\
\hline 5 & - & - & $+1-$ & + & ++ & - \\
\hline 6 & - & - & + & - & + & - \\
\hline
\end{tabular}




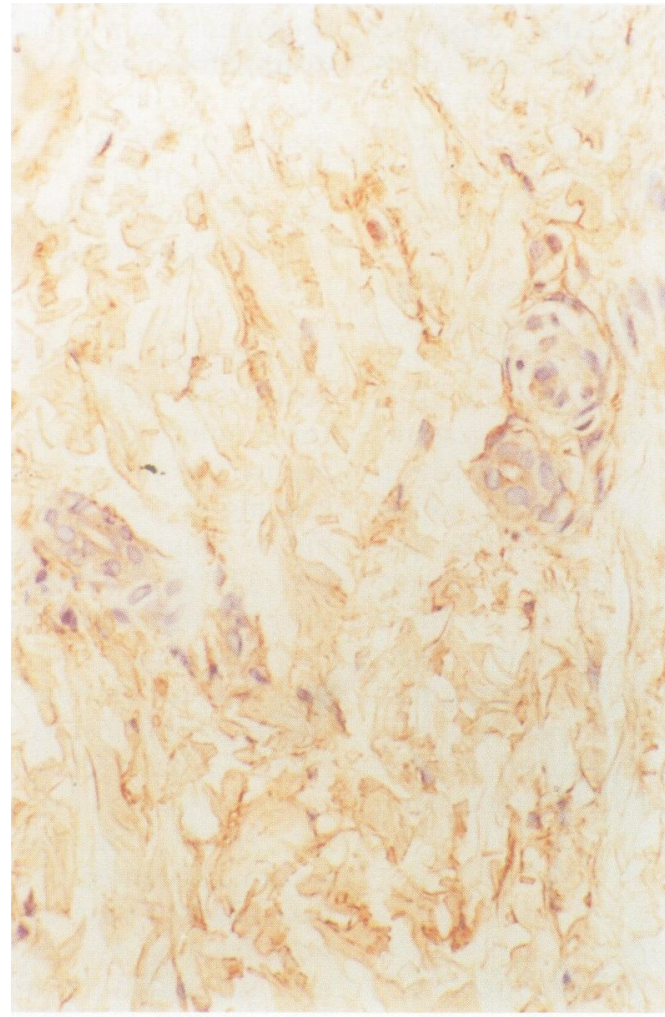

(A)

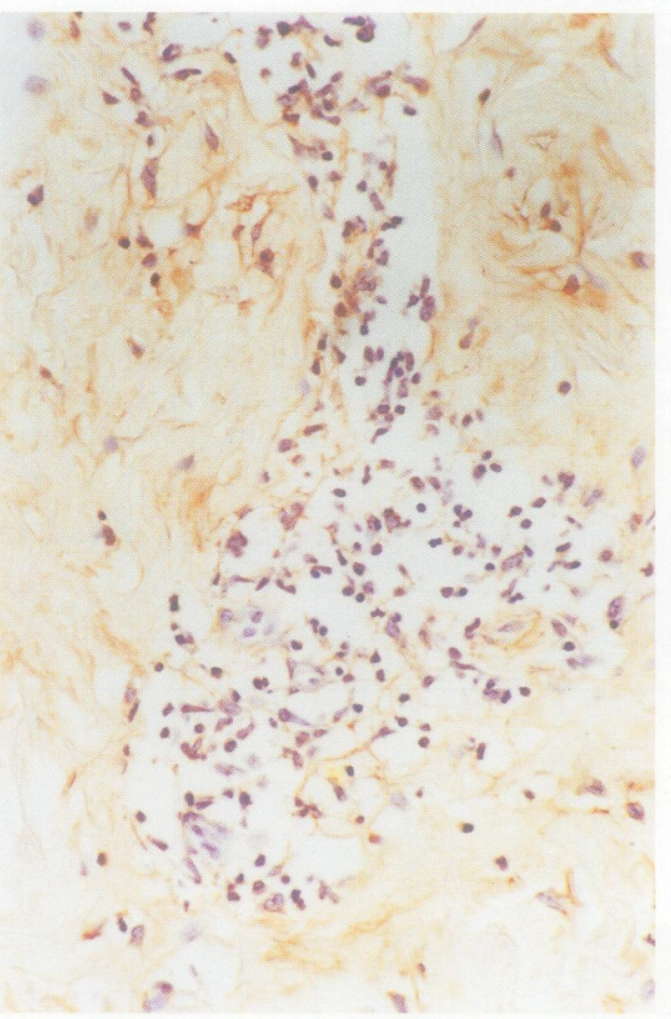

(C)

Figure 1 TGF- $\beta$ immunostaining with haematoxylin counterstain $(\times 430)$ of sections from biopsy specimens of $(A)$ normal skin, (B) skin five days after a tuberculin Heaf test, $(C)$ skin 13 days after a tuberculin Heaf test, and (D) skin five days after a tuberculin Heaf test but with antibody to TFG- $\beta$ omitted.

day 5 (fig 2B). Type 1 procollagen immunostaining was maximal in biopsy specimens obtained on day 13 (fig $2 \mathrm{C}$ ). On day 5 , the grades were from + to +++ for peri-

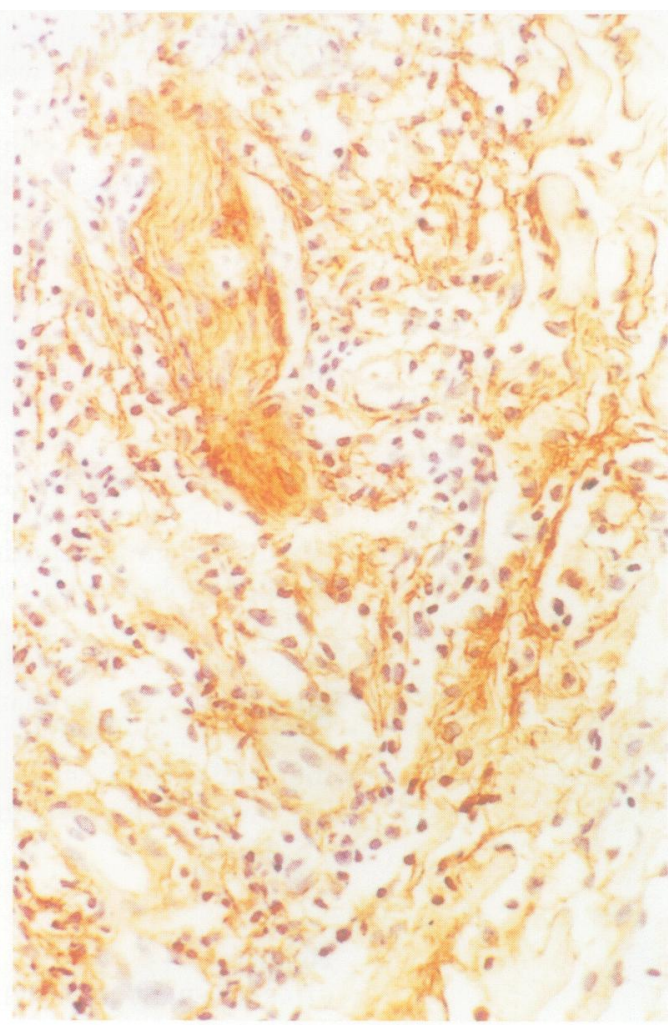

(B)

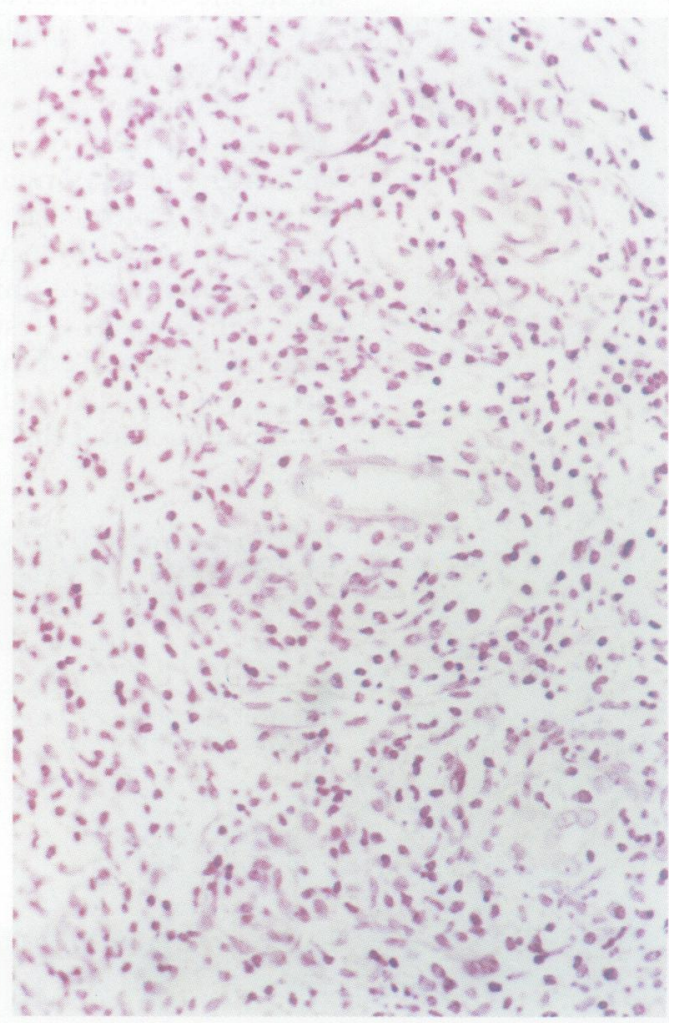

(D)

vascular and from + to ++ for cellular staining. The grades increased to ++ to +++ for perivascular and to + to +++ for cellular staining on day 13 after the tuberculin Heaf 


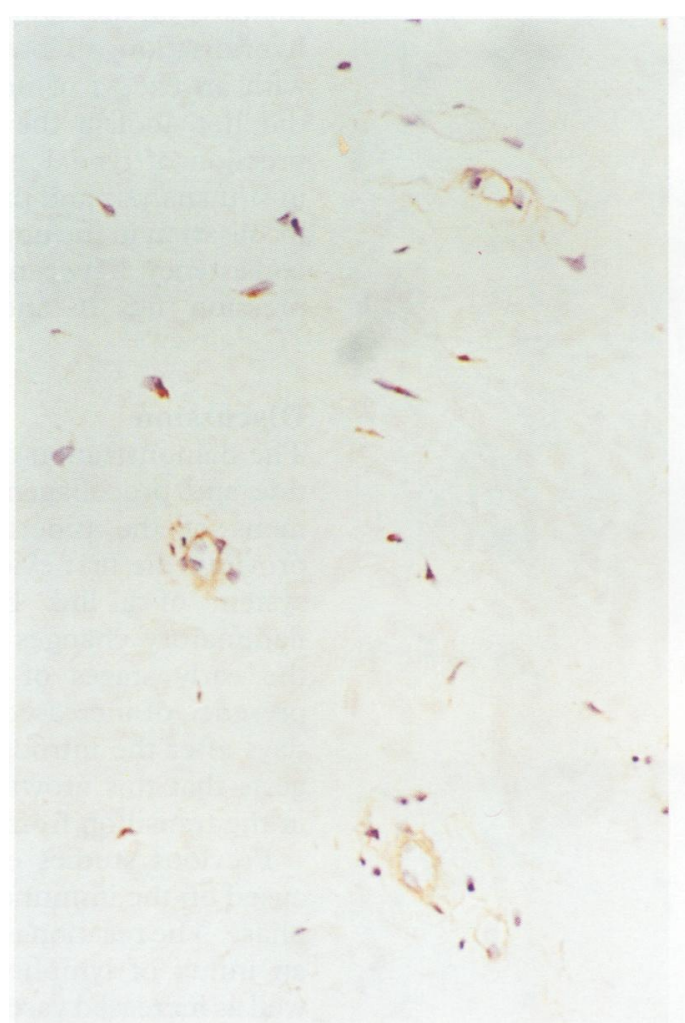

(A)

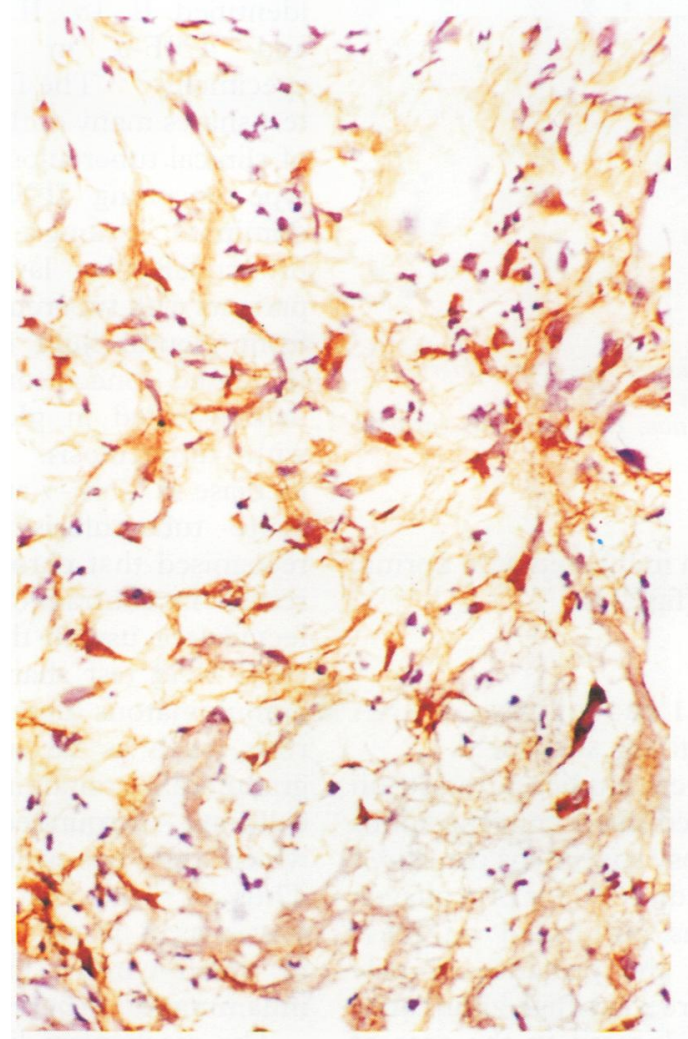

(C)

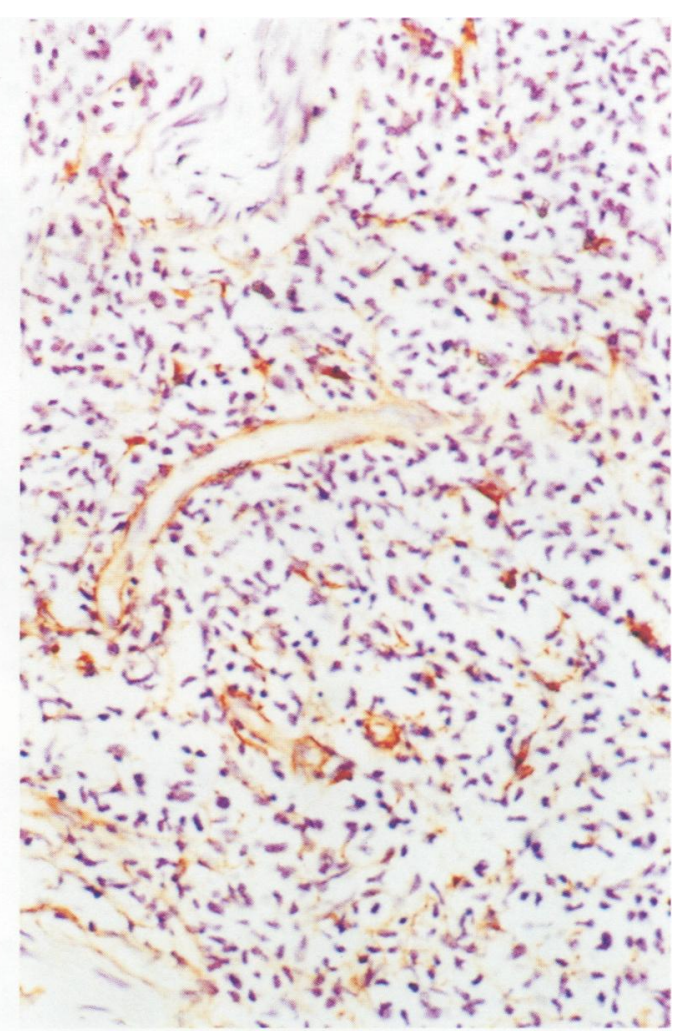

(B)

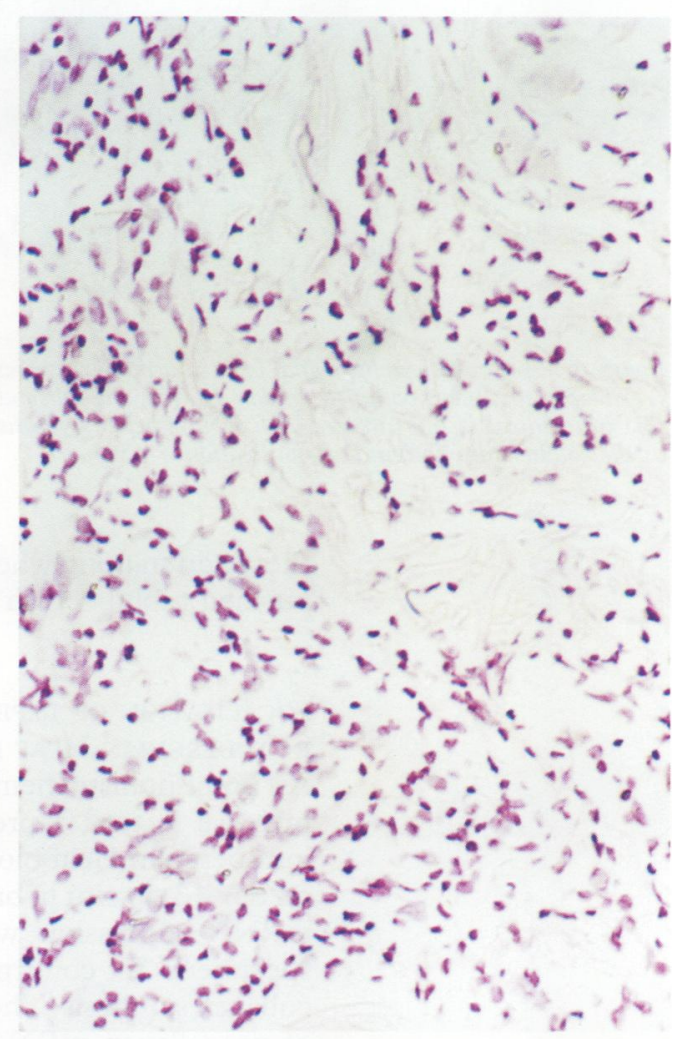

(D)

Figure 2 Type 1 procollagen immunostaining with haematoxylin counterstain $(\times 450)$ of sections from biopsy specimens of $(A)$ normal skin, (B) skin five days after a tuberculin Heaf test, $(C)$ skin 13 days after a tuberculin Heaf test and, (D) skin five days after a tuberculin Heaf test but with antibody to type 1 procollagen omitted.

test (table). Cellular staining was observed predominantly in cells with the morphology of fibroblasts. In biopsy specimens obtained $42-$ 120 days after the tuberculin Heaf test peri- vascular staining was similar to that observed in normal skin. However, some cells still stained strongly for type 1 procollagen. Sections from tuberculin Heaf test biopsy specimens did not 


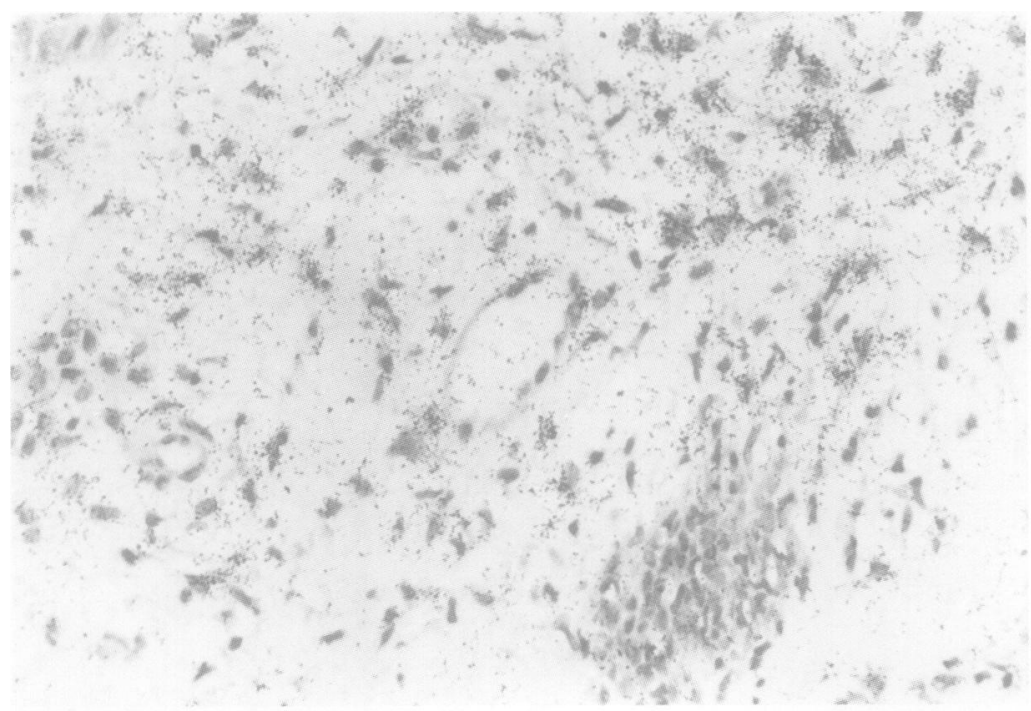

(A)

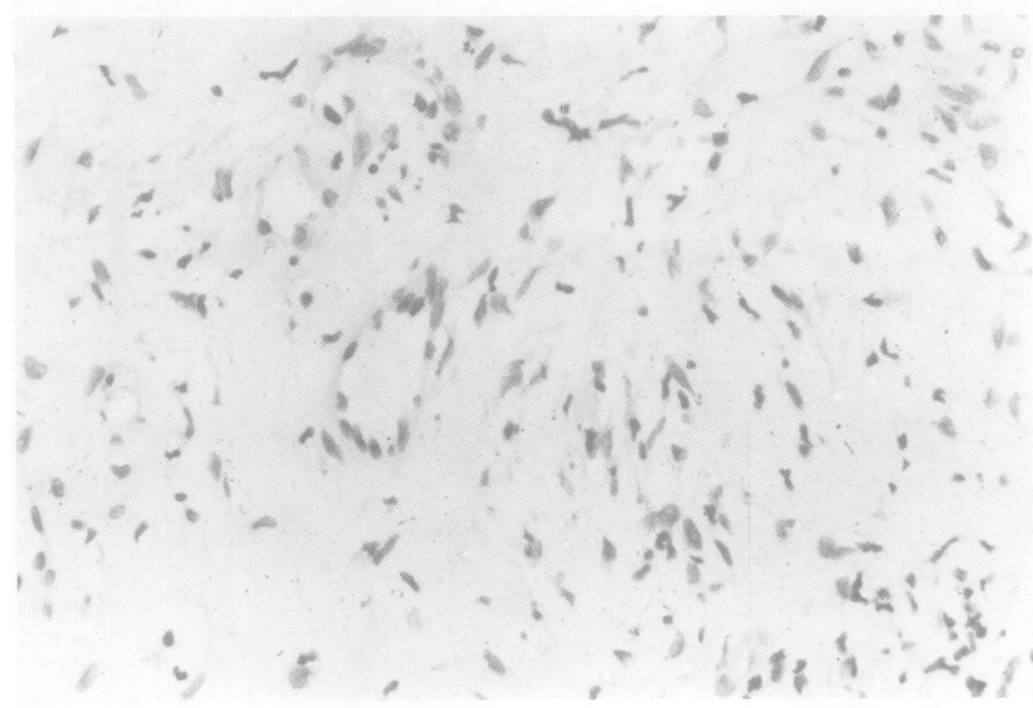

(B)

Figure 3 Autoradiographic signal of in situ $m R N A$ expression of type 1 procollagen in (A) biopsy specimens obtained on day 13 after the tuberculin Heaf test and

(B) in identical sections treated with RNase before hybridisation. Haematoxylin was used as the counterstain (original magnification $\times 450$ ).

show any staining when incubated with normal purified rabbit serum (fig 2D).

LOCALISATION OF TYPE 1 PROCOLLAGEN MRNA IN TUBERCULIN HEAF BIOPSY SPECIMENS

As immunohistochemical studies revealed an increase in type 1 procollagen concentrations in tuberculin Heaf biopsy specimens measured on day 13, in situ hybridisation for procollagen mRNA expression was performed on these specimens to confirm the presence of new collagen synthesis. There was a high abundance of procollagen mRNA located in the area of cellular infiltration (fig 3A). Procollagen mRNA was occasionally observed in the perivascular areas in these specimens. Type 1 procollagen mRNA was not observed in sections from biopsy specimens on day 13 which were treated with ribonuclease $\mathrm{A}$ and $\mathrm{T} 1$ before hybridisation (fig 3B). In other experiments the hybridisation signal was abolished by prehybridization of sections with a 50 -fold excess of "cold" (that is, unlabelled) antisense probe mixture of the same oligonucleotides before hybridisation. Conversely, prehybridisation with an excess of unlabelled irrelevant probe did not abolish the signal. The regional expression of type 1 procollagen mRNAs using in situ analysis and their immunohistochemical localisation in the upper dermal region revealed consistency between mRNA and protein expression (figs $2 \mathrm{C}$ and $3 \mathrm{~A}$ ).

\section{Discussion}

The demonstration of type 1 procollagen peptide and procollagen mRNA in biopsy specimens of the tuberculin tests in this study provides the first evidence in a human in vivo system of a link between the chronic inflammatory changes of a DTH response and the early stages of a fibrotic reaction. The presence of increased amounts of TGF- $\beta$, five days after the introduction of tuberculin, suggests that this growth factor may be involved in the transition from inflammation to fibrosis.

Previous studies on the Heaf test have focused on the immunological and inflammatory phase. The reaction is characterised by oedema, an influx of lymphocytes and monocytes, as well as increased vascular permeability. ${ }^{19-21}$ The lymphocytes have been shown to be of the Th- 1 subtype in that they encode IFN- $\gamma$ and IL-2. ${ }^{10}$ Immunohistochemical techniques have identified IL- $1 \alpha$, IL- $1 \beta$, IL-2, IL- 6 , IFN- $\gamma$, and TNF- $\alpha$ in tuberculin test biopsy specimens. ${ }^{2022}$ The DTH response of the Heaf test shares many of the immunological features of clinical tuberculosis. Cells of the Th-1 subtype encoding IFN- $\gamma$, but not IL-5, predominate amongst $\mathrm{T}$ cells obtained by bronchoalveolar lavage from the lungs of patients with tuberculosis ${ }^{8}$ and amongst $T$ cells from pleural fluid in tuberculous pleuritis. ${ }^{9}$ Increased concentrations of IFN- $\gamma$ have been demonstrated in pleural fluid from patients with tuberculosis. ${ }^{23}$ Similarly, there is an increase in TNF- $\alpha$ and IL- 6 concentrations in acute tuberculosis. ${ }^{24}$ Clinically, it is also recognised that chronic tuberculosis infection results in contraction and fibrosis of the infected area, usually the upper lobes. The tuberculin Heaf test shares similarities with other granulomatous diseases which progress to fibrosis, such as sarcoidosis. In this condition granulomas containing lymphocytes and giant cells are surrounded by collagen, much of which stains positively for type 1 procollagen. ${ }^{25}$ Thus, it seems that the tuberculin Heaf test serves as a useful model for these diseases in which chronic immunologically mediated inflammation progresses to fibrosis.

The mechanism linking the immunological events of a DTH response with a fibrotic reaction is not known. Animal studies examining monokine production in granulomas which resolve or progress to fibrosis have suggested that the production of growth factors is critical to the eventual outcome. ${ }^{26}$ We have previously provided evidence that, via the production of IFN- $\gamma$, antigen stimulated lymphocytes may increase the mRNA of the potent fibroblast growth factor PDGF(B). ${ }^{411}$ In the present study 
PDGF(B) concentrations were not measured because of difficulties with antibody binding to formalin fixed, paraffix wax sections. However, an increase in the abundance of TFG- $\beta$ protein was observed on day 5. This was largely extracellular and may reflect either increased local production or matrix deposition. Antibodies that can discriminate between intra- and extracellular TGF- $\beta^{27}$ were not available for this study. TGF- $\beta$ is an important product of many cells. It causes increased collagen type- 1 gene expression, ${ }^{28}$ collagen protein production by fibroblasts in vitro ${ }^{29}$ and enhanced wound healing in vivo. ${ }^{12}$ TGF-1 $\beta$ is present in increased amounts in lungs of patients with lung fibrosis ${ }^{56}$ as well as in fibrotic diseases of other organs. ${ }^{30}$ The temporal association in the present study between the increase in TGF- $\beta$ concentrations on day 5 and the increase in type 1 procollagen mRNA and protein levels on day 13 leads to the speculation that these events may be causally related. The measurement of expression of various TFG- $\beta$ isoforms involved in these skin biopsy specimens on day 5 is currently in progress.

The present study describes a human in vivo model in which immunologically mediated chronic inflammation progresses to a fibrotic reaction. We believe this model provides a useful tool to dissect the relation between chronic inflammation and fibrosis. The model also offers an accessible site on which to test new therapeutic strategies which may prevent the progression of inflammation to fibrosis.

This study was supported by the Medical Research Council and British Lung Foundation.

1 Watters LC, Schwarz MI, Cherniack RM, Waldron JA, Dunn TL, Stanford RE, et al. Idiopathic pulmonary fibrosis: Pretreatment bronchoalveolar lavage cellular conrosis: Pretreatment bronchoalveolar lavage cellular constituents and their relationships with lung histopathology
and clinical response to therapy. Am Rev Respir Dis 1987; and clinical respc

2 Nagaoka I, Trapnell BC, Crystal RG. Upregulation of platelet-derived growth factor-A and -B gene expression in alveolar macrophages of individuals with idiopathic pulmonary fibrosis. f Clin Invest 1990;85:2023-37.

3 Antoniades HN, Bravo MA, Avila RE, Galanopoulous T, Neville-Golden J, Maxwell $\mathrm{M}$, et al. Platelet-derived growth factor in idiopathic pulmonary fibrosis. $\mathcal{f}$ Clin Invest 1990;86:1055-64.

4 Shaw RJ, Benedict SH, Clark RAF, King TE Jr. Pathogenesis of pulmonary fibrosis in interstitial lung disease. Alveolar macrophage PDGF(B) gene activation and up-regulation macrophage PDGF(B) gene activation and up-regulation
by interferon gamma.Am Rev Respir Dis 1991;143:167-73.

5 Khalil N, O'Connor RN, Unruh HW, Warren PW, Flanders $\mathrm{KC}$, Kemp $\mathrm{A}$, et al. Increased production and immunohistochemical localization of transforming growth factor-beta in idiopathic pulmonary fibrosis. Am $\mathcal{f}$ Respir Cell Mol Biol 1991;5:155-62.

6 Broekelmann TJ, Limper AH, Colby TV, McDonald JA. Transforming growth factor beta 1 is present at sites of extracellular matrix gene expression in human pulmonary fibrosis. Proc Natl Acad Sci USA 1991;88:6642-6.

7 Barnes PF, Abrams JS, Lu S, Sieling PA, Rea TH, Modlin RL. Patterns of cytokine production by mycobacterium$\mathrm{RL}$. Patterns of cytokine production by mycobacterium-
reactive human T cell clones. Infect Immun 1993;61:197reactive

8 Robinson DS, Sun Ying, Taylor IK, Wangoo A, Mitchell $\mathrm{DM}, \mathrm{Kay} \mathrm{AB}$, et al. Evidence for a Th-1 like brochoalveolar T-cell subset and predominance of IFN-g gene activation in pulmonary tuberculosis. Am $\mathcal{F}$ Respir Crit Care Med 1994;149:989-93.
9 Barnes PF, Lu S, Abrams JS, Wang E, Vamamura $M$, Modlin RL. Cytokine production at the sites of disease in human tuberculosis. Infect Immun 1993;61:3482-9.

10 Tsicopoulos A, Hamid Q, Varney V, Ying S, Moqbel R, Durham SR, et al. Preferential messenger RNA expression of Th1-type cells (IFN-gamma,$+ \mathrm{IL}-2+$ ) in classical delayed type (tuberculin) hypersensitivity reactions in delayed type (tuberculin) hypersensitivity
human skin. $f$ Immunol 1992;148:2058-61.

11 Wangoo A, Taylor IK, Haynes AR, Shaw RJ. Upregulation of alveolar macrophage PDGF-B mRNA by interferonof amma from $M$ tuberculosis antigen (PPD) stimulated lymphocytes. Clin Exp Immunol 1993;94:43-50.

12 Pierce GF, Mustoe TA, Lingelbach J, Masakowski VR, Griffin GL, Senior RM, et al. Platelet derived growth factor and transforming growth factor-beta enhance tissue repair activities by unique mechanisms. F Cell Biol 1989; 109:429-40.

13 McDonald JA, Broekelmann TJ, Matheke ML, Crouch E, Koo M, Kuhn C. A monoclonal antibody to the carboxyterminal domain of procollagen type 1 visualizes collagen-sythesizing fibroblasts. $₹$ Clin Invest 1984;78: collagen-syth

14 de Wet W, Bernards M, Chanda VB, Chu ML, Dickson L, Weil D, et al. Organization of the human Pro-a2(1) collagen gene. f Biol Chem 1987;262:16032-6.

15 Peltonen J, Hsiao LL, Jaakkola S, Solberg S, Aumilley M, Timpl R. Activation of collagen gene expression in keloids: Colocalization of type 1 and VI collagen and transforming growth factor-b1 mRNA. F Invest Dermatol 1991;97:240-8.

16 Warburton MJ, Fernes SA, Hughes CM, Sear CH, Rudland PS. Generation of cell types with myoepithelial and mesenchymal phenotypes during the conversation of rat mammary tumor epithelial stem cells in to elongated cells. m Natl Cancer Inst 1987;78:1191-201.

17 Taylor M, Cook T, Pearson C, Risdon RA, Peart S. Renin messenger RNA localisation in congenital mesoblastic nephroma using in situ hybridization. $f$ Hypertens 1989; 7:733-40.

18 Bernard MP, Chu ML, Myers JC, Ramirez F, Eikenberry EF, Prockop DJ. Nucleotide sequences of complementary deoxyribonucleic acids for the Proal chain of human type 1 procollagen. Statistical evaluation of structures that are conserved during evolution. Biochemistry 1983;22:5213 23.

19 Poulter LW, Seymour GJ, Duke O, Janossy G, Panayi G. Immunohistological analysis of delayed type hy-

20 Fullmer MA, Shen JY, Modlin RL, Rea TH. Immunohistological evidence of lymphokine production and lymphocyte activation antigens in tuberculin reactions. Clin Exp Immunol 1987;67:383-90.

21 Konttinen YT, Bergroth V, Visa-Tolranen K, Reitamo S, Forstrom $L$. Cellular infiltrate in situ and response kinetics of human intradermal and epicutaneous tuberculin reactions. Clin Immunol Immunopathol 1983;28:441-9.

22 Chu CQ, Field M, Andrew E, Haskard D, Feldmann M, Maini RN. Detection of cytokines at the site of tuberculininduced delayed-type hypersensitivity in man. Clin Exp Immunol 1992;90:522-9.

23 Ribera E, Espanol T, Martinez-Vazquez JM, Ocana I, Encabo G. Lymphocyte proliferation and gamma-interferon production after in vitro stimulation with PPD. Differences between tuberculous and nontuberculous pleurisy in patients with positive tuberculin skin test. Chest 1990;97: 1381-5.

24 Ogawa T, Uchida H, Kusumoto Y, Mori Y, Yamamura Y, Hamada S. Increase in tumor necrosis factor alpha and IL-6 secreting cells in peripheral blood mononuclear cells from subjects infected with Mycobacterium tuberculosis. Infect Immun 1991;59:3021-5.

25 Perez RL, Jeon YJ, Staton GW Jr, Roman J. Role of extracellular matrices, matrix receptors, and cytokines in tracellular matrices, matrix receptors, and cytokines in (Supp1 2):S86-7.

26 Lemaire I. Selective differences in macrophage populations and monokine production in resolving pulmonary granuloma and fibrosis. Am f Pathol 1991;138:487-95.

27 Flanders KC, Thompson NL, Cissel DS, Van-ObberghenSchilling E, Baker CC, Kass ME. Transforming growth factor beta-1: Histochemical localization with antibodies to different epitopes. $\mathcal{f}$ Cell Biol 1989;108:653-60.

28 Quaglino D Jr, Nanney LB, Kennedy R, Davidson JM. Transforming growth factor-beta stimulates wound healing and modulates extracellular matrix gene expression in pig skin. Lab Invest 1990;63:307-19.

29 Ignotz RA, Massague J. Transforming growth factor-beta stimulates the expression of fibronectin and collagen and their incorporation in to the extracellular matrix. $\mathcal{F} \mathrm{Biol}$ Chem 1986;261:4337-45.

30 Yoshioka K, Takemura T, Murakami K, Okadi M, Hino $\mathrm{S}$, Miyamoto $\mathrm{H}$, et al. Transforming growth factor-beta protein and $\mathrm{mRNA}$ in glomeruli in normal and diseased human kidneys. Lab Invest 1993;68:154-63. 